\title{
Serum profiles of androstenedione, testosterone and LH from birth through puberty in buffalo bull calves
}

\author{
N. A. Hemeida, Y. R. El-Baghdady and M. A. El-Fadaly \\ Department of Surgery and Theriogenology, Faculty of Veterinary Medicine, Cairo University, Giza, \\ Egypt
}

\begin{abstract}
Summary. Blood samples were taken once per week for 4-7 weeks from 59 buffalo calves in 14 age groups, 1-2 months apart. Hormones were quantified by validated radioimmunoassays. Values of androstenedione and testosterone were low at birth $(141.3 \pm 33.5 \mathrm{pg} / \mathrm{ml}$ and $18.0 \pm 2.9 \mathrm{pg} / \mathrm{ml}$, respectively; mean \pm s.d. $)$. Serum androstenedione concentrations gradually increased from birth until 8 months of age and declined $(P<0.05)$ thereafter, whereas mean testosterone values were low up to 8 months and then significantly $(P<0.05)$ increased as age advanced. LH concentrations averaged $2 \cdot 12 \pm 0.47 \mathrm{ng} / \mathrm{ml}$ at birth. Thereafter, a decline in LH values was followed by an increase between 6 and 15 months of age. We conclude that, in buffalo bull calves, the pubertal period occurs from about 8 to 15 months of age. For pubertal buffalo bulls 15-17 months of age, serum concentrations of androstenedione, testosterone and $\mathrm{LH}$ were $156.9 \pm 54.6 \mathrm{pg} / \mathrm{ml}, 208.4 \pm 93.8 \mathrm{pg} / \mathrm{ml}$ and $2 \cdot 10 \pm 0.70$ $\mathrm{ng} / \mathrm{ml}$, respectively.
\end{abstract}

\section{Introduction}

Despite the great number of studies devoted to androstenedione, testosterone and LH concentrations in peripheral blood in bull calves (Bos taurus) (MacMillan \& Hafs, 1968; Rawlings, Hafs \& Swanson, 1972; Schams \& Butz, 1972; Karg et al., 1976; Secchiari, Martorana, Pellegrini \& Luisi, 1976; Lacroix, Garnier \& Pelletier, 1977; Rawlings, Fletcher, Henricks \& Hill, 1978; Lacroix \& Pelletier, 1979; McCarthy, Hafs \& Convey, 1979; Sundby \& Velle, 1980; Amann \& Walker, 1983), similar studies on hormonal changes in buffalo bull calves (Bubalus bubalis) are still lacking.

Puberty in Egyptian buffaloes (defined as the age when an ejaculate is obtained containing 10 $\times 10^{6}$ spermatozoa $/ \mathrm{ml}$ at which $10 \%$ or more are motile: Wolf, Almquist \& Hale, 1965) takes place at a mean age of 17 months (Hemeida \& Badawy, 1981). For dairy and beef bulls, puberty occurs at the age of 8-11 and 11-12 months respectively, while Brahman bulls reach puberty at 16 months of age (Almquist \& Cunningham, 1967; Lunstra, Ford \& Echternkamp, 1978; Fields, Hentges \& Cornelisse, 1982). In most species, LH and testosterone are critical regulators of male sexual maturation. As yet no reports have been published on $\mathrm{LH}$ and testosterone secretory patterns in pubertal buffalo bulls.

The present attempt was, therefore, undertaken to study the changes in peripheral androstenedione, testosterone and LH concentrations in buffalo bull calves from birth through puberty.

\section{Materials and Methods}

\section{Animals}

The 59 buffalo bull calves, ranging in age from birth to 19 months, were allotted to 14 age groups, 1-2 months apart, with each group including 3-6 animals. All buffaloes were born on a farm near Cairo where they had been kept under the same conditions. They were fed according to conventional feeding standards (Chalmers, 1974). 


\section{Collection of samples}

Blood samples were collected by venepuncture from the jugular vein once per week for 4-7 weeks from each animal. All collections were made at $08: 00$ h over 3 months from March to May. The buffalo calves were accustomed to handling and the samples could be taken with minimal restraint. Blood samples were allowed to clot at $4^{\circ} \mathrm{C}$, then serum was harvested by centrifugation at $2000 \mathrm{~g}$ for $30 \mathrm{~min}$. Serum was stored at $-20^{\circ} \mathrm{C}$ until assayed.

\section{Radioimmunoassays}

Testosterone and androstenedione. Antisera against testosterone and androstenedione were kindly supplied by Dr B. Hoffmann, Institute of Physiology, Munich University, West Germany. Testosterone concentrations were determined on toluene: petroleum ether $(2: 5 \mathrm{v} / \mathrm{v})$ extracts of buffalo serum following the procedure of Karg et al. (1976). The samples were assayed in duplicate. The antibody used to assay testosterone cross-reacted considerably $(54 \%)$ only with $5 \alpha$-dihydrotestosterone, but it was assumed that the DHT concentration in buffalo serum was negligible because no differences were observed in plasma testosterone concentrations of developing bull calves before or after separation of DHT by thin-layer chromatography, although the DHT crossreacted strongly with the antibody used (Karg et al., 1976; Lacroix et al., 1977). The sensitivity of the assay, the smallest concentration significantly distinguishable from zero, was $0.3 \mathrm{pg} / \mathrm{tube}$. The intra-assay coefficient of variation averaged $8.6 \%$ and the inter-assay variation was $13.6 \%$.

Androstenedione concentrations were assessed on toluene : petroleum ether $(2: 5 \mathrm{v} / \mathrm{v})$ extracts of buffalo serum using a procedure identical to that employed for testosterone. The sensitivity of the assay, intra- and inter-assay coefficients of variation were $1.3 \mathrm{pg} /$ tube, $9.0 \%$ and $14.8 \%$, respectively.

The average recovery of testosterone (from 50 to $200 \mathrm{pg}$ ) added to $200 \mu \mathrm{l}$ samples of buffalo cow serum was $83.5 \pm 11 \cdot 2 \%$. After addition of androstenedione $(50-200 \mathrm{pg})$ to $300 \mu \mathrm{l}$ buffalo cow serum, recovery of androstenedione was $85.0 \pm 9.7 \%$. Parallelism was also determined by quantitating testosterone and androstenedione in different volumes of serum from a buffalo bull and an anoestrous buffalo cow. Toluene: petroleum ether $(2: 5 \mathrm{v} / \mathrm{v})$ extracts of 150 to $350 \mu \mathrm{l}$ buffalo serum gave results parallel to the standard curves for testosterone or androstenedione.

$L H$. Serum LH concentrations were estimated by a double-antibody, non-equilibrium assay with rabbit 15 antibody (Niswender, Reichert, Midgley \& Nalbandov, 1969). The standard employed in this assay was NIH-LH-B9. The sensitivity of the assay was $0.4 \mathrm{ng} /$ tube. The intraassay coefficient of variation averaged $8.9 \%$ and the interassay variation was $16.0 \%$.

Further validation of the assay was accomplished by showing parallelism of different volumes of pooled buffalo serum samples to the standard curve (Text-fig. 1) and by demonstrating recovery of added NIH-LH-B9 to buffalo cow and bull serum. After addition of $\mathrm{LH}(80,160,320 \mathrm{pg})$ to $200 \mu \mathrm{l}$ serum samples of buffalo bulls and anoestrous buffalo cows, recovery of LH was $88.2 \pm 9 \cdot 0 \%$.

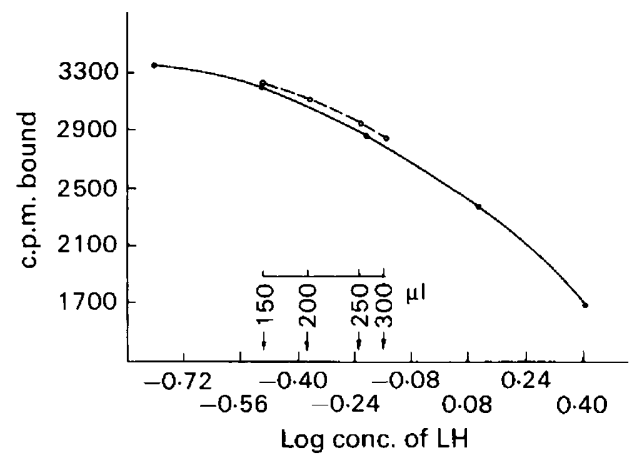

Text-fig. 1. Parallelism of different volumes of buffalo bull serum (---) to the standard curve of LH (-). 


\section{Statistical analyses}

Hormone concentrations in samples obtained at birth and during 1-2-month periods were grouped together (mean \pm s.d.). The effect of age on hormone concentrations was determined by one-way analysis of variance. If the F-value was significant, differences amongst means were evaluated by the Studentized Range $Q$ method and were considered to be significant if $P<0.05$ (Snedecor \& Cochran, 1976).

\section{Results}

The mean concentrations ( \pm s.d.) of androstenedione, testosterone and $\mathrm{LH}$ at birth and for each 12-month period throughout the study are shown in Text-fig. 2. Age influenced both androstenedione $(P<0.05)$ and testosterone $(P<0.01)$ concentrations. Serum concentrations of androstenedione were low at birth $(141.3 \pm 33.5 \mathrm{pg} / \mathrm{ml})$ but gradually increased with age. After a statistically significant drop $(P<0.05)$ at $8-9$ months of age, serum androstenedione values gradually decreased as age advanced, reaching its lowest level at $17-19$ months of age $(106 \cdot 0 \pm 35 \cdot 3 \mathrm{pg} / \mathrm{ml})$.

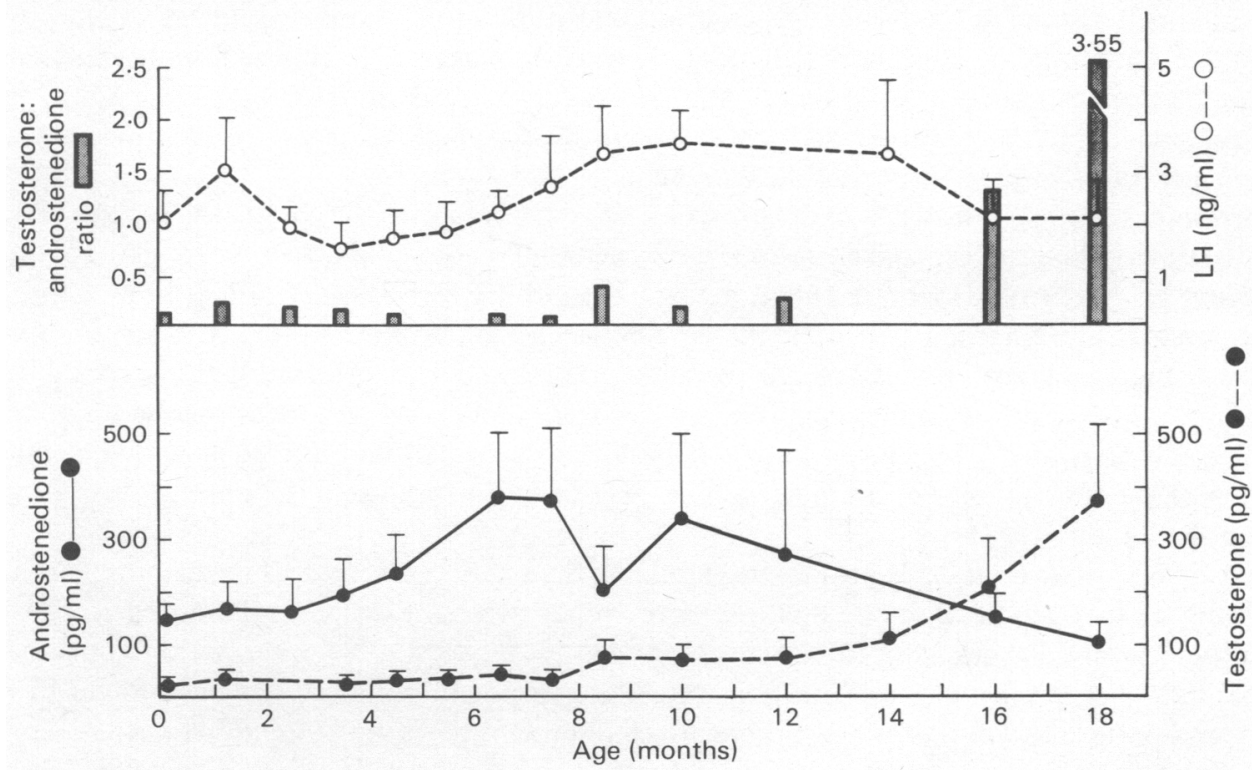

Text-fig. 2. Serum profiles of androstenedione, testosterone and LH in buffalo bulls from birth through puberty. Values are mean \pm s.d.

Testosterone concentrations were very low $(18.0 \pm 2.9 \mathrm{pg} / \mathrm{ml})$ in serum of buffalo bull calves at birth and remained low up to 8 months of age $(26.0-40.6 \mathrm{pg} / \mathrm{ml})$. The first significant increase $(P<$ $0.05)$ in serum testosterone occurred at $8-9$ months of age. The onset of a second rise $(P<0.05)$ in testosterone concentrations at 13-15 months of age was followed by a linear and sharp increase with advancing age, reaching $376.2 \pm 139.7 \mathrm{pg} / \mathrm{ml}$ serum in 17-19-month-old buffalo bulls.

The testosterone:androstenedione ratios remained low (between $0 \cdot 1$ to $0 \cdot 2$ ) for the first 8 months of life (Text-fig. 2). Marked increases $(P<0.05)$ were noted at $8-9$ and $15-19$ months of age $(0.4$ and 3.6 respectively).

LH values in sera of buffalo bull calves were high at birth $(2.12 \pm 0.47 \mathrm{ng} / \mathrm{ml})$ and showed an 
early rise in the first few weeks of life. Serum concentrations of LH decreased to a nadir (1.48 \pm $0.45 \mathrm{ng} / \mathrm{ml}$ ) at 3-4 months of age, followed by gradual increases as age advanced to reach a plateau $(3.29-3.50 \mathrm{ng} / \mathrm{ml})$ between 8 and 15 months of age. Thereafter, serum LH values decreased with advancing age and averaged $2.14 \pm 0.56 \mathrm{ng} / \mathrm{ml}$ in $17-19-$ month-old buffalo bulls.

\section{Discussion}

The present serum androstenedione profile in buffalo bull calves conflicts with the findings of Lindner (1969), Singal \& Gomes (1978) and Bedair \& Thibier (1979) who noted increases at 2-4 months and a decrease to negligible values after 5-6 months of age in bull calves (Bos taurus). However, a pattern similar to serum testosterone concentrations in buffalo bull calves has been found at earlier ages in domestic bull calves (Lindner, 1959; MacMillan \& Hafs, 1969; Rawlings et al., 1972; Karg et al., 1976). Peripheral testosterone concentrations have also been described as showing an oscillatory pattern after 6.5 months of age (Secchiari et al., 1976) or to increase at a linear rate with age (Karg et al., 1976; Lunstra et al., 1978; McCarthy et al., 1979; Thun, Leuch, Eggenberger \& Zerobin, 1980; Fields et al., 1982; Amann \& Walker, 1983) in young bull calves. This discrepancy might be due to species and breed differences, seasonal variation, nutritional factors and differences in frequency of sampling and number of animals (Lunstra et al., 1978; Sundby \& Tollman, 1978; Lacroix \& Pelletier, 1979). Also, season of birth was found to influence testosterone profiles (Amann \& Walker, 1983). However, Karg et al. (1976) and Secchiari et al. (1976) concluded that there is no evidence of seasonal effect, as bulls born at different times showed a similar testosterone pattern during development.

The serum $\mathrm{LH}$ profile recorded in the present study disagrees with the conflicting reports on $\mathrm{LH}$ concentrations in bull calves; concentrations have been found not to vary with age (Schams \& Butz, 1972; Karg et al., 1976), to increase between 1 and 7 months (Rawlings et al., 1972; Mori, Masaki, Wakabayashi, Endo \& Hosoda, 1974), to increase between 3 and 4 months only (Amann \& Walker, 1983), or to increase from 7 months of age to adulthood (Gombe, Hall, McEntee, Hansel \& Pickett, 1973). Some of these discrepancies could be due in part to a pulsatile pattern of release (Gombe et al., 1973; Thibier, 1975; McCarthy et al., 1979; Schanbacher, 1981) and to insufficient blood sampling or the low number of animals studied. Season of birth had no influence on LH profile (Amann \& Walker, 1983).

Study of testosterone and LH profiles in 3 buffalo bulls aged 1.5 to 2 years showed number of LH peaks ranging from no peak in one bull to 2 in the other two bulls, whereas the number of testosterone peaks varied from 1 to 10 (Chantaraprateep et al., 1981). No information concerning seasonal influences on gonadotrophins and testicular steroids in buffaloes has been found in the available literature. In Bos taurus bulls, there are conflicting reports in the literature with regard to seasonal variation in LH and testosterone secretion (Thibier, 1975, 1976; Karg et al., 1976; Secchiari et al., 1976; Sundby \& Tollman, 1978; Amann \& Walker, 1983).

The finding that serum testosterone increased steeply in buffalo bulls 13-15 months of age or older, in spite of the rather constant LH concentrations, could be attributed to higher testicular sensitivity to LH as pubertal development proceeds (Catt, 1977) or to the fact that higher levels of testosterone, approaching the physiological concentration of the adult, suppress LH secretion (Lee et al., 1976; D'Occhio, Schanbacher \& Kinder, 1982). In Bos taurus bulls, a further increase in systemic concentration of testosterone occurs until at least 36 months of age (Hafs \& McCarthy, 1979).

For many species, the pubertal period is associated with rapid testicular growth, increased secretion of gonadotrophins, secretion of testosterone in response to discharges of $\mathrm{LH}$ and initiation of spermatogenesis. The most dramatic changes occurred from 5 to 9 months of age in Bos taurus bulls (Rawlings et al., 1972; 1978; Lunstra et al., 1978; Thun et al., 1980; Curtis \& Amann, 1981; Schanbacher, 1981; Amann \& Schanbacher, 1983). Results from the present study indicate that, in buffalo bull calves, the pubertal period occurs from about 8 to 15 months of age. 
For pubertal buffalo bulls 15-19 months of age, strum androstenedione and LH concentrations were comparable with values reported for pubertal dairy and beef bulls (Thibier, 1975; Lacroix et al., 1977; Bedair \& Thibier, 1979; McCarthy et al., 1979). The concentration of peripheral testosterone in buffalo bulls was much lower than that in Bos taurus bulls (Katongole, Naftolin \& Short, 1971; Karg et al., 1976; Thibier, 1976; Rawlings et al., 1978; Amann \& Walker, 1983).

The radioimmunoassays were conducted at the Department of Veterinary Biosciences, College of Veterinary Medicine, Urbana, Illinois, U.S.A., utilizing laboratory facilities under the direction of Dr J. Hixon. We thank Dr P. G. Weston for technical assistance.

\section{References}

Almquist, J.O. \& Cunningham, D.C. (1967) Reproductive capacity of beef bulls. 1. Post-pubertal changes in semen production at different ejaculation frequencies. J. Anim. Sci. 26, 174-181

Amann, R.P. \& Schanbacher, B.D. (1983) Physiology of male reproduction. J. Anim. Sci. 57 (Suppl. 2), 380403.

Amann, R.P. \& Walker, O.A. (1983) Changes in the pituitary gonadal axis associated with puberty in Holstein bulls. J. Anim. Sci. 57, 433-442.

Bedair, G.A. \& Thibier, M. (1979) Peripheral plasma androstenedione and testosterone concentrations in bulls before and during puberty. J. Reprod. Fert. 56, 7-10.

Catt, K.J. (1977) Summary of the proceedings of fourth testis workshop. Mol. cell. Endocr. 9, 129.

Chalmers, M.I. (1974) Nutrition. In The Husbandry and Health of the Domestic Buffalo, pp. 167-194. Ed. W. R. Cockrill. FAO, Rome.

Chantaraprateep, P., Kamonpatana, M., Lohachit, C., Kunawongkrit, A., Verakul, P., Bodhipaksha, P. \& Ngramsuriyaraj, C. (1981) Circadian variations of plasma LH and testosterone in adult Swamp buffalo bulls. Theriogenology 15, 161-171.

Curtis, S.K. \& Amann, R.P. (1981) Testicular development and establishment of spermatogenesis in Holstein bulls. J. Anim. Sci. 53, 1645-1657.

D'Occhio, M.J., Schanbacher, B.D. \& Kinder, J.E. (1982) Relationship between serum testosterone concentration and patterns of luteinizing hormone secretion in male sheep. Endocrinology 110, 1547-1554.

Fields, M.J., Hentges, J.F. \& Cornelisse, K.W. (1982) Aspects of the sexual development of Brahman versus Angus bulls in Florida. Theriogenology 18, 1731.

Gombe, S., Hall, W.C., McEntee, K., Hansel, w. \& Pickett, B.W. (1973) Regulation of blood levels of LH in bulls: influence of age, breed, sexual stimulation and temporal fluctuation. J. Reprod. Fert. 35, 493503.

Hafs, H.D. \& McCarthy, M.S. (1979) Endocrine control of testicular function. In Animal Reproduction, pp. 345-364. Ed. H. W. Hawk. Allanheld, Osmum \& Co., Montclair.

Hemeida, N.A. \& Badawy, A.B.A. (1981) Puberal and post-puberal changes in semen characteristics of buffalo bulls. Egypt. Vet. Med. J. Cairo Univ. 28, 303310.
Karg, H., Giménez, T., Hartl, M., Hofimann, B., Schallenberger, E. \& Schams, D. (1976) Testosterone, luteinizing hormone (LH) and follicle stimulating hormone (FSH) in peripheral plasma of bulls: levels from birth through puberty and short term variations. Zentbl. VetMed. A23, 793-803.

Katongole, C.B., Naftolin, F. \& Short, R.V. (1971) Relationships between blood levels of luteinizing hormone and testosterone in bulls, and the effect of sexual stimulation. J. Endocr. 50, 457-466.

Lacroix, A. \& Pelletier, J. (1979) Short-term variations in plasma LH and testosterone in bull calves from birth to I year of age. J. Reprod. Fert. 55, 81-85.

Lacroix, A., Garnier, D.H. \& Pelletier, J. (1977) Temporal fluctuations of plasma $\mathrm{LH}$ and testosterone in Charolais bull calves during the first year of life. Annls Biol. anim. Biochim. Biophys. 17, 1013-1019.

Lee, V.W.K., Cumming, I.A., de Kretser, D.M., Findlay, J.K., Hudson, B. \& Keogh, E.J. (1976) Regulation of gonadotrophin secretion in rams from birth to sexual maturity. 1. Plasma LH, FSH and testosterone levels. J. Reprod. Fert. 46, 1-6.

Lindner, H.R. (1959) Androgens in the bovine testis and spermatic vein blood. Nature, Lond. 183, 1605-1606.

Lindner, H.R. (1969) The androgenic secretion of the testis in domestic ungulates. In The Gonads, pp. 615 648. Ed. K. W. McKerns. North-Holland, Amsterdam.

Lunstra, D.D., Ford, J.J. \& Echternkamp, S.E. (1978) Puberty in beef bulls: Hormone concentrations, growth, testicular development, sperm production and sexual aggressiveness in bulls of different breeds. J. Anim. Sci. 46, 1054-1062.

MacMillan, K.L. \& Hafs, H.D. (1968) Pituitary and hypothalamic endocrine changes associated with reproductive development of Holstein bulls. J. Anim. Sci. 27, 1614-1620.

MacMillan, K.L. \& Hafs, H.D. (1969) The reproductive tract of Holstein bulls from birth through puberty. $J$. Anim. Sci. 28, 233-239.

McCarthy, M.S., Hafs, H.D. \& Convey, E.M. (1979) Serum hormone patterns associated with growth and sexual development in bulls. J. Anim. Sci. 49, 10121020 .

Mori, J., Masaki, J., Wakabayashi, K., Endo, T. \& Hosoda, T. (1974) Serum luteinizing hormone levels in cattle under various reproductive states. Theriogenology 1, 131-136.

Downloaded from Bioscientifica.com at 04/26/2023 11:05:30AM 
Niswender, G.D., Reichert, L.E., Jr, Midgley, A.R., Jr \& Nalbandov, A.V. (1969) Radioimmunoassay for bovine and ovine luteinizing hormone. Endocrinology 84, $1166-1173$.

Rawlings, N.C., Hafs, H.D. \& Swanson, L.V. (1972) Testicular and blood plasma androgens in Holstein bulls from birth through puberty. J. Anim. Sci. 34, 435-440.

Rawlings, N.C., Fletcher, P.W., Henricks, D.M. \& Hill, J.R. (1978) Plasma luteinizing hormone (LH) and testosterone levels during sexual maturation in beef bull calves. Biol. Reprod. 19, 1108-1113.

Schams, D. \& Butz, H.D. (1972) Plasma level of luteinizing hormone in female and male calves from birth until puberty. Proc. 7th Int. Congr. Anim. Reprod. \& A.I., Munich, pp. 2175-2178.

Schanbacher, B.D. (1981) Importance of the episodic nature of luteinizing hormone secretion for normal development of the bovine testis during puberty: interference with oestradiol-17ß. J. Endocr. 88, 393400.

Secchiari, P., Martorana, F., Pellegrini, S. \& Luisi, M. (1976) Variation of plasma testosterone in developing Friesian bulls. J. Anim. Sci. 42, 405-409.

Singal, S.P. \& Gomes, W.R. (1978) A radioimmunoassay study on blood androgens in Angus bulls at different stages of development. Indian vet. J. 55, 687-691.
Snedecor, G.W. \& Cochran, W.G. (1976) Statistical Methods, 6th edn, pp. 258-275. Iowa State University Press, Ames.

Sundby, A. \& Tollman, R. (1978) Plasma testosterone in bulls : seasonal variation. Acta vet. scand. 19, 263-268.

Sundby, A. \& Velle, W. (1980) Plasma concentration of testosterone in young bulls in relation to age, rate of weight gain and stimulation with human chorionic gonadotrophin. J. Endocr. 85, 465-469.

Thibier, M. (1975) Variations circadiennes de la LH plasmatique chez le jeune taurillon. Annls Endocr. (Paris), 36, 205-210.

Thibier, M. (1976) Diurnal testosterone and 17 $\alpha$ hydroxyprogesterone levels in peripheral plasma of young post pubertal bulls. A study by frequent sampling. Acta endocr., Copenh. 81, 623-634.

Thun, R., Leuch, F., Eggenberger, E. \& Zerobin, K. (1980) Plasma testosterone concentrations in bulls with intact and shortened scrotums during sexual maturation. Biol. Reprod. 22, 765-771.

Wolf, F.R., Almquist, J.O. \& Hale, E.B. (1965) Prepubertal behaviour and puberal characteristics of beef bulls on high nutrient allowance. J. Anim. Sci. 24, 761-765.

Received 23 May 1984 